\title{
Increased Expression of CD40 Ligand on Systemic Lupus Erythematosus Lymphocytes
}

\author{
Mary Koshy, Douglas Berger, and Mary K. Crow \\ The Specialized Center for Research in Systemic Lupus Erythematosus and the Department of Medicine, The Hospital for Special Surgery \\ and Cornell University Medical College, New York, New York 10021
}

\begin{abstract}
The specificity of $\mathrm{T}$ cell help for $\mathrm{B}$ cell activation and differentiation is maintained by the brief expression on the $T$ cell surface, following $\mathrm{T}$ cell receptor-mediated triggering, of CD40 ligand (CD40L). Interaction of $T$ helper $\left(T_{h}\right)$ cell CD40L with B cell CD40 induces B cell activation, cell surface expression of activation antigens, proliferation, and initiation of immunoglobulin isotype switch. We predicted that in patients with systemic lupus erythematosus (SLE), in whom $T_{h}$ cell-dependent production of autoantibodies results in immune complex-mediated tissue damage, CD40L expression might be augmented, prolonged, or abnormally regulated. Baseline expression of $\mathrm{CD} 40 \mathrm{~L}$ was increased in some SLE patients studied, when compared with control subjects. While $T_{h}$ cells from normal subjects $(n=14)$ and rheumatic disease control patients $(n=9)$ showed maximal expression of CD40L, after in vitro activation with phorbol myristate acetate (PMA) and ionomycin, at $6 \mathrm{~h}$ of culture with diminished levels observed at 24 and $48 \mathrm{~h}, \mathrm{~T}_{\mathrm{h}}$ cells from SLE patients $(n=19)$ maintained high level cell surface expression of CD40L through 24 and $48 \mathrm{~h}$ of culture. The prolonged expression of CD40L was functionally significant, as $24 \mathrm{~h}$-activated SLE T cells, when cocultured with target B cells, induced greater B cell surface CD80 (B7-1) expression than did $24 \mathrm{~h}$-activated normal $\mathrm{T}$ cells. These results document impaired regulation of CD40L expression in SLE $T$ cells and identify an important potential target for therapy in this systemic autoimmune disease. (J. Clin. Invest. 1996. 98:826-837.) Key words: CD40 ligand • T lymphocytes • lupus erythematosus $\bullet$ systemic $\bullet$ lymphocyte activation • autoimmunity
\end{abstract}

\section{Introduction}

In situ formation or deposition of circulating immune complexes mediates the tissue and organ damage that results in disease in patients with systemic lupus erythematosus (SLE). ${ }^{1}$ Recent investigations have supported the important roles of

Address correspondence to Mary K. Crow, M.D., The Hospital for Special Surgery, 535 East 70th Street, New York, NY 10021. Phone: 212-606-1397; FAX: 212-717-1192; E-mail: crowm@hss.edu

Received for publication 23 October 1995 and accepted in revised form 4 June 1996.

1. Abbreviations used in this paper: CD40L, CD40 ligand; CLL, chronic lymphocytic leukemia; MCF, mean channel fluorescence; PDB, phorbol dibutyrate; TCR, T cell receptor; $\mathrm{T}_{\mathrm{h}}, \mathrm{T}$ helper.

J. Clin. Invest.

(C) The American Society for Clinical Investigation, Inc.

0021-9738/96/08/0826/12 \$2.00

Volume 98, Number 3, August 1996, 826-837 defined autoantigens, as well as autoantigen-specific $T$ helper $\left(T_{h}\right)$ cells, in the induction of the autoantibodies that comprise these pathogenic immune complexes (1-10). As in specific immune responses to most antigens, autoantibody production is likely to depend on interaction of self antigen with B cell surface immunoglobulin receptors and the receipt of B cell surface signals mediated by direct interaction with the $T_{h}$ cell surface, as well as $\mathrm{T}_{\mathrm{h}}$ cell-derived cytokines $(11,12)$.

The binding of the CD40 ligand (CD40L; TBAM; gp39) molecule on the $T_{h}$ cell surface to $B$ cell surface CD40 is the molecular event that mediates direct $\mathrm{T}$ cell help for $\mathrm{B}$ cell activation (13-21). Studies of B cell CD40 ligation, along with delineation of the immunologic consequences of the hyperIgM syndrome, attributable to a variety of mutations in the $\mathrm{X}$ chromosome-encoded gene for CD40L (22-28), have defined the important role of CD40L-CD40 binding in B cell function. The induction of $\mathrm{B}$ cell surface expression of CD23, CD80 (B7-1), and Apo-1 (Fas) (16, 29-32); B cell proliferation (30, $33)$; germinal center formation $(34,35)$; and the initiation of $\mathrm{Ig}$ class switch from IgM to more mature B cell isotypes (16-21, 34-36) are among the effects of CD40 ligation. Given the important consequences of CD40 signaling for regulation of humoral immunity, rigorous regulation of T cell CD40L expression is necessary to maintain the antigen specificity of the immune response. Consistent with this suggestion, $\mathrm{T}$ cell receptor (TCR)-mediated $\mathrm{T}$ cell activation results in rapid, but brief, expression of cell surface CD40L on CD4+ T cells (37). Studies using phorbol myristate acetate (PMA) and ionomycin, to mimic the biochemical consequences of TCR signaling, have shown maximal expression of CD40L at 6 hours, with diminution of expression by $24 \mathrm{~h}$ of culture (37-39).

We have investigated the regulation of CD40L expression in patients with SLE, a systemic autoimmune disease characterized by $\mathrm{B}$ cell activation, hypergammaglobulinemia, and unregulated production of $\mathrm{IgG}$ autoantibodies. We predicted that increased, prolonged, or abnormally regulated expression of CD40L after $\mathrm{T}$ cell activation might contribute to the humoral immune dysfunction that is the basis for the pathophysiology of SLE.

\section{Methods}

Study subjects. Patients with SLE $(n=19)$, meeting at least four of the American College of Rheumatology revised criteria for the diagnosis of SLE (40), were followed at The Hospital for Special Surgery Rheumatic Disease Clinic. Peripheral blood samples were obtained with permission of the patients. Disease control subjects $(n=9)$ included five patients with seropositive rheumatoid arthritis (RA), one patient with progressive systemic sclerosis, two patients with Reiter's syndrome, and one patient with autoimmune thyroid disease. Normal controls $(n=14)$ included healthy approximately age-matched volunteers. Table I shows the age, sex, race, and medical therapy being administered to the subjects in each study group. In addition, relative disease activity for SLE and disease control groups is noted. For SLE patients, activity rating of 3 represents nephritis, serositis, or central 


\begin{tabular}{|c|c|c|c|c|c|c|c|}
\hline Subjects & Diagnosis & Age & Race & Sex & $\begin{array}{l}\text { Disease } \\
\text { activity }\end{array}$ & Medications & $\begin{array}{l}\text { Change in } \\
\text { percent CD } 40 \mathrm{~L}+ \\
\text { from } 6 \text { to } 24 \mathrm{~h}\end{array}$ \\
\hline \multicolumn{8}{|c|}{ A. SLE Patients } \\
\hline 1 & & 30 & $\mathrm{C}$ & $\mathrm{F}$ & 3 & MTX, Pred > 10 & $\Uparrow 12$ \\
\hline 2 & & 46 & $\mathrm{H}$ & $\mathrm{F}$ & 2 & Pred $\leq 10$ & $\Uparrow 12$ \\
\hline 3 & & 60 & $\mathrm{C}$ & $\mathrm{F}$ & 3 & Pred $\leq 10$ & $\Uparrow 11$ \\
\hline 4 & & 39 & AA & $\mathrm{F}$ & 3 & Hycl, Pred $\leq 10$ & $\Uparrow 10$ \\
\hline 5 & & 29 & AA & $\mathrm{F}$ & 2 & Hycl, Pred $>10$ & $\Uparrow 10$ \\
\hline 6 & & 33 & $\mathrm{C}$ & M & 2 & Hycl, Pred $\leq 10$ & $\Uparrow 7$ \\
\hline 7 & & 34 & AA & $\mathrm{F}$ & 2 & NA & $\Uparrow 3$ \\
\hline 8 & & 50 & $\mathrm{C}$ & M & 2 & Aza, Pred $>10$ & $\Uparrow 2$ \\
\hline 9 & & 47 & AA & $\mathrm{F}$ & 2 & Pred $>10$ & $\Uparrow 2$ \\
\hline 10 & & 35 & AA & $\mathrm{F}$ & 3 & MTX, Pred $\leq 10$ & 0 \\
\hline 11 & & 51 & AA & $\mathrm{F}$ & 3 & Pred $\leq 10$ & 0 \\
\hline 12 & & 41 & $\mathrm{C}$ & $\mathrm{F}$ & 3 & Cyt, Pred $>10$ & 0 \\
\hline 13 & & 40 & AA & $\mathrm{F}$ & 1 & NA & $\Downarrow_{2}$ \\
\hline 14 & & 41 & $\mathrm{C}$ & $\mathrm{F}$ & 3 & Pred $\leq 10$ & $\Downarrow_{2}$ \\
\hline 15 & & 31 & AA & $\mathrm{F}$ & 3 & Hycl, Pred $>10$ & $\Downarrow_{2}$ \\
\hline 16 & & 40 & $\mathrm{H}$ & $\mathrm{F}$ & 2 & NA & $\Downarrow_{5}$ \\
\hline 17 & & 42 & $\mathrm{H}$ & $\mathrm{F}$ & 3 & Aza, Pred $\leq 10$ & $\Downarrow_{7}$ \\
\hline 18 & & 29 & $\mathrm{H}$ & $\mathrm{F}$ & 1 & none & $\Downarrow_{10}$ \\
\hline 19 & & 49 & $\mathrm{C}$ & $\mathrm{F}$ & 3 & Aza, Hycl, Pred $\leq 10$ & $\Downarrow_{24}$ \\
\hline \multicolumn{8}{|c|}{ B. Disease Controls } \\
\hline 1 & RA & 70 & $\mathrm{C}$ & $\mathrm{F}$ & NA & NA & $\Uparrow 14$ \\
\hline 2 & RA & 45 & AA & $\mathrm{F}$ & 3 & Pred $\leq 10$ & 0 \\
\hline 3 & $\begin{array}{l}\text { Autoimm } \\
\text { thyroiditis }\end{array}$ & 33 & $\mathrm{C}$ & $\mathrm{F}$ & 1 & none & $\Downarrow_{10}$ \\
\hline 4 & PSS & 38 & $\mathrm{H}$ & $\mathrm{F}$ & 3 & ASA & $\Downarrow_{10}$ \\
\hline 5 & RA & 35 & $\mathrm{H}$ & $\mathrm{F}$ & 2 & MTX & $\Downarrow 15$ \\
\hline 6 & Reiter's & 50 & $\mathrm{C}$ & $\mathrm{F}$ & 2 & NSAID & $\Downarrow_{22}$ \\
\hline 7 & RA & 48 & AA & $\mathrm{F}$ & NA & Pred $\leq 10$ & $\Downarrow_{25}$ \\
\hline 8 & RA & 55 & $\mathrm{H}$ & $\mathrm{F}$ & NA & Pred $\leq 10$ & $\Downarrow_{25}$ \\
\hline 9 & Reiter's & 50 & $\mathrm{C}$ & $\mathrm{F}$ & 1 & NSAID & $\Downarrow 35$ \\
\hline \multicolumn{8}{|c|}{ C. Healthy Controls } \\
\hline 1 & & 22 & $\mathrm{C}$ & M & 0 & none & $\Uparrow 9$ \\
\hline 2 & & 55 & $\mathrm{H}$ & $\mathrm{F}$ & 0 & none & $\Uparrow 3$ \\
\hline 3 & & 23 & AA & $\mathrm{F}$ & 0 & none & $\Downarrow_{8}$ \\
\hline 4 & & 47 & $\mathrm{C}$ & $\mathrm{F}$ & 0 & none & $\Downarrow_{8}$ \\
\hline 5 & & 33 & $\mathrm{C}$ & $\mathrm{F}$ & 0 & none & $\Downarrow_{9}$ \\
\hline 6 & & 58 & $\mathrm{C}$ & $\mathrm{F}$ & 0 & none & $\Downarrow_{11}$ \\
\hline 7 & & 35 & $\mathrm{H}$ & M & 0 & none & $\Downarrow_{19}$ \\
\hline 8 & & 22 & $\mathrm{C}$ & M & 0 & none & $\Downarrow_{25}$ \\
\hline 9 & & 43 & $\mathrm{C}$ & $\mathrm{F}$ & 0 & none & $\Downarrow_{25}$ \\
\hline 10 & & 20 & $\mathrm{C}$ & M & 0 & none & $\Downarrow_{26}$ \\
\hline 11 & & 38 & $\mathrm{C}$ & $\mathrm{F}$ & 0 & none & $\Downarrow_{27}$ \\
\hline 12 & & 28 & A & M & 0 & none & $\Downarrow_{27}$ \\
\hline 13 & & 55 & AA & $\mathrm{F}$ & 0 & none & $\Downarrow_{32}$ \\
\hline 14 & & 27 & $\mathrm{C}$ & $\mathrm{M}$ & 0 & none & $\Downarrow_{34}$ \\
\hline
\end{tabular}

Study subjects are characterized by age, sex and race (C, Caucasian; H, Hispanic; AA, African American; A, Asian). Relative disease activity is described as 0 (no disease), 1 (inactive disease), 2 or 3 (active disease, as defined in Methods). Immunosuppressive medications used at the time of lymphocyte assay are noted as MTX (methotrexate), Hycl (hydroxychloroquine), Aza (azathioprine), Cyt (cytoxan), Pred (prednisone, either $\leq 10$ mg/ day or $>10 \mathrm{mg} /$ day). The change in percent of mononuclear cells positive for CD40L from 6 to $24 \mathrm{~h}$ after in vitro activation with PMA and ionomycin is noted ( $\Uparrow$ designates an increase in percent $\mathrm{CD} 40 \mathrm{~L}+; 0$ designates no change; and $\Downarrow$ designates a decrease in percent CD40L + over this time period). $N A$, not available. 
nervous system disease; activity rating of 2 represents active skin disease, arthralgias or arthritis, or mild proteinuria; activity rating of 1 represents inactive SLE. For RA patients, activity rating of 3 signifies severe polyarticular synovitis with nodules or organ involvement; activity rating of 2 represents polyarticular arthritis. The PSS patient, with an activity rating of 3 , had facial and upper extremity skin tightening, digital ulcerations, mild restrictive pulmonary disease, and serum anti-Scl70 autoantibody. One of the Reiter's syndrome patients (rating of 2) had lower extremity arthritis and iritis and the other (rating of 1) had mild arthralgias. Immunosuppressive medications administered at the time of assay are noted.

Cell cultures. Peripheral blood mononuclear cells (PBMC) were isolated on Ficoll-Hypaque and incubated at $37^{\circ} \mathrm{C}, 5 \% \mathrm{CO}_{2}$ for 6,24 , or $48 \mathrm{~h}$ in culture medium containing RPMI 1640 (GIBCO BRL, Gaithersburg, MD), 10\% fetal calf serum (Whittaker Bioproducts, Inc., Walkersville, MD), $2 \mathrm{mM}$ glutamine, and $50 \mathrm{U} / \mathrm{ml}$ penicillin and streptomycin (GIBCO BRL). $1 \times 10^{6} \mathrm{PBMC}$ were cultured in $1 \mathrm{ml}$ culture medium alone or with $5 \mathrm{ng} / \mathrm{ml}$ PMA or phorbol dibutyrate (PDB; Sigma Chemical Co., St. Louis, MO) and $500 \mathrm{ng} / \mathrm{ml}$ ionomycin (Sigma Chemical Co.).

Monoclonal antibodies $(m A b)$. mAb used included OKT3 (antiCD3, pan-T); OKT4 (anti-CD4, helper/inducer subset); and OKT8 (anti-CD8, suppressor/cytotoxic subset) (American Type Culture Collection, Rockville, MD). mAb anti-Tac, reactive with the p55 chain of the IL-2 receptor (CD25), was obtained from Dr. Thomas Waldmann (National Institutes of Health). mAb reactive with human CD40L included mAb 5c8 (13; kindly provided by Drs. Seth Lederman and Michael Yellin, Columbia University College of Physicians and Surgeons, NY) and anti-CD40L (PharMingen, San Diego, CA). mAb EBVCS (anti-CD23) was obtained from Drs. Stan Metzenberg and Bill Sugden (McCardle Institute for Cancer Research, Madison, Wisconsin), anti-B7-1 (CD80) was obtained from Becton Dickinson, Cockeysville, MD, and anti-CD19 (pan-B cell) was purchased from PharMingen.

Indirect immunofluorescence. $1 \times 10^{5} \mathrm{PBMC}$ or B cells were incubated with buffer alone or with a saturating concentration of $\mathrm{mAb}$ at $4^{\circ} \mathrm{C}$ for $30 \mathrm{~min}$. After three washes in buffer, cells were incubated with a saturating concentration of fluorescein-labeled $\mathrm{F}\left(\mathrm{ab}^{\prime}\right)_{2}$ fragments of goat anti-mouse IgG (Tago, Inc., Burlingame, CA) at $4^{\circ} \mathrm{C}$ for $30 \mathrm{~min}$. After three washes in buffer, cell fluorescence was ana- lyzed on a FACScan ${ }^{\circledR}$ cytofluorograph or an Ortho cytofluorograph, gating on the lymphocyte population. Percent of cells positive and mean channel fluorescence, above the level of fluorescence of cells stained with the fluorescein-labeled goat anti-mouse $\mathrm{IgG}$ alone, were recorded for each sample. Most FACS analyses were performed by a single investigator (MK) using standard cytofluorograph parameters. Peak and mean background fluorescence and setting of regions for positive fluorescence were comparable in different experimental settings. When possible (in nine experiments), SLE and control subjects were studied in parallel in a single assay.

Multiparameter analysis was performed using 2-fluorochromes to determine CD40L expression on lymphocyte populations. Propidium iodide binding cells, representing poorly viable cells, were excluded from the analysis.

Induction of cell surface activation antigen expression on target $B$ cells. In some experiments, $1 \times 10^{6}$ normal or SLE PBMC were incubated for 6,24 , or $48 \mathrm{~h}$ with culture medium alone or with PDB and ionomycin, as described above. The cells were then washed three times with Hank's Balanced Salt Solution, resuspended in $1 \mathrm{ml}$ fresh culture medium, and irradiated with 1000R from a Cesium source. $1 \times$ $10^{6}$ precultured cells were incubated with $0.5 \times 10^{6}$ Ramos B cells (a Burkitt's lymphoma-derived cell line; ATCC), human tonsillar B cells, or B cells from a patient with chronic lymphocytic leukemia (CLL) in a total volume of $2 \mathrm{ml}$ culture medium at $37^{\circ} \mathrm{C}, 5 \% \mathrm{CO}_{2}$. After an additional $24 \mathrm{~h}$ of culture, the cells were harvested, prepared for indirect immunofluorescence analysis as above, and assessed for expression of CD23, CD80, and CD19.

Statistical analysis. The mean \pm standard deviation (SD) for $\% \mathrm{CD} 40 \mathrm{~L}+$ mononuclear cells and for MCF was determined for each subject group, at each time point, and for each culture condition. Statistically significant differences between SLE and control groups were defined using the Student's $t$ test.

\section{Results}

Expression of CD40L on SLE PBMC. Previous experiments by others have documented the rapid kinetics of expression of CD4+ T cell surface CD40L after T cell activation through the TCR (37-39). In most studies, TCR signaling has been mim-

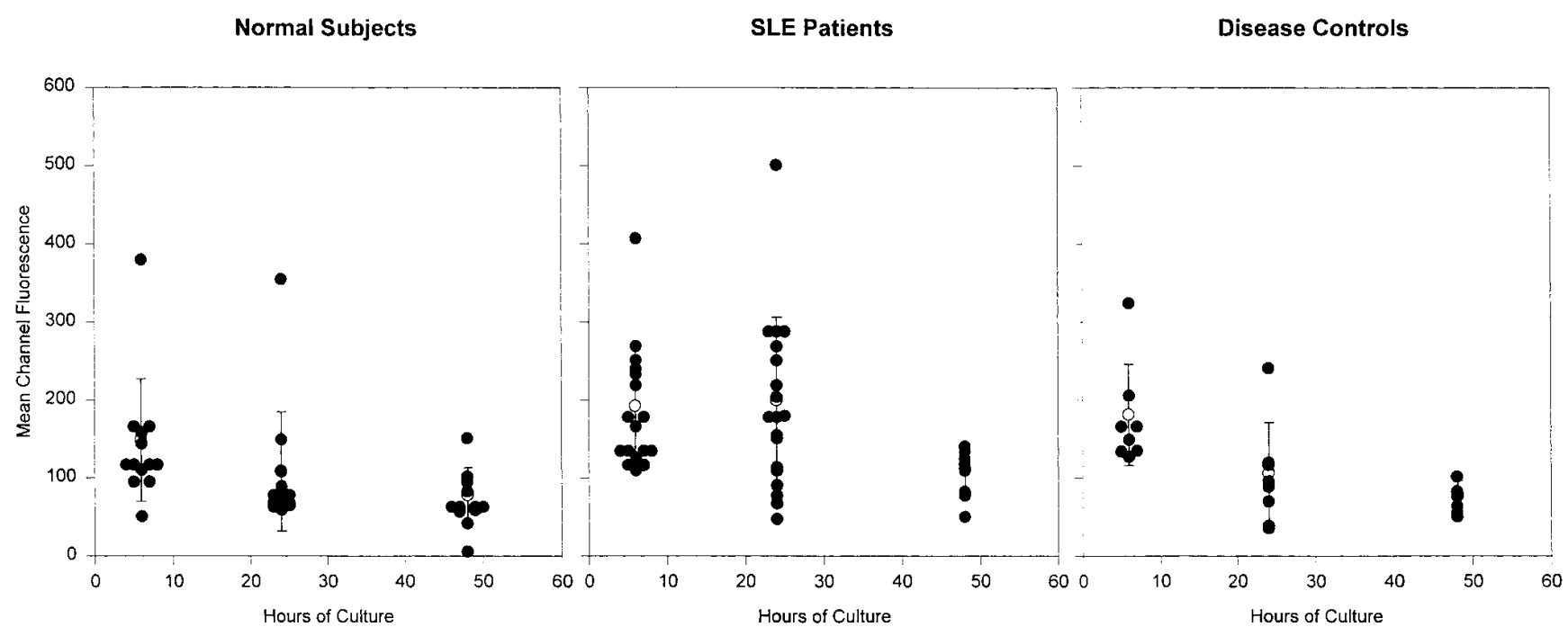

Figure 1. Kinetics of mean fluorescence intensity CD40L expression on in vitro activated PBMC. PBMC from normal subjects (left panel), SLE patients (center panel), or disease control subjects (right panel) were cultured for 6, 24, or $48 \mathrm{~h}$ with PMA and ionomycin and then assessed by indirect immunofluorescence for expression of CD40L. Results are expressed as MCF of the population of gated cells that were in the region to the right of the upper limit of the background fluorescence histogram. The mean (open circles) and standard deviation for each study population at each time point are shown. 


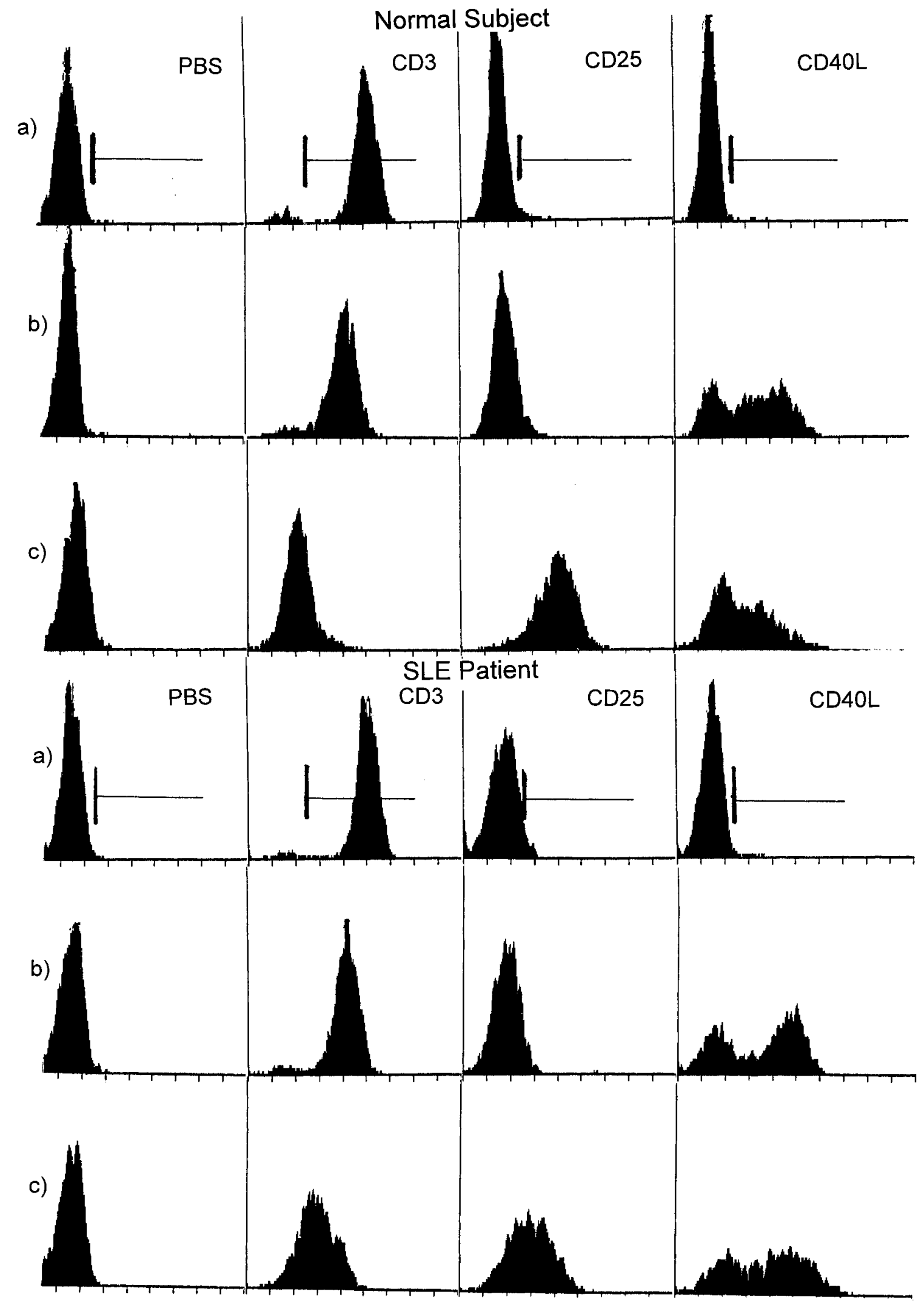

Figure 2. Kinetics of CD40L expression on PMA and ionomycin-activated PBMC from a normal subject (top) and a patient with SLE (bottom). PBMC from a healthy subject and a patient with SLE were cultured in parallel for 6 hours with medium alone $(a)$ or with PMA and ionomycin for $6 \mathrm{~h}(b)$ or $24 \mathrm{~h}(c)$ and then analyzed by indirect immunofluorescence and FACS for background staining (PBS), or CD3, CD25, or CD40L expression. Cell number is shown on the Y axis and fluorescence intensity (log scale) on the $x$-axis of each histogram. 
Table II. Kinetics of CD40 Ligand and CD25 Expression on PBMC Activated with PMA and Ionomycin

\begin{tabular}{|c|c|c|c|c|c|c|c|c|}
\hline \multirow[b]{3}{*}{ Hours of activation } & \multicolumn{8}{|c|}{ Average mean channel fluorescence for study population } \\
\hline & \multicolumn{4}{|c|}{ CD40 ligand } & \multicolumn{4}{|c|}{$\mathrm{CD} 25$} \\
\hline & 0 & 6 & 24 & 48 & 0 & 6 & 24 & 48 \\
\hline Normal subjects & $\begin{array}{c}49.6 \pm 16.7 \\
(10)\end{array}$ & $\begin{array}{c}141.0 \pm 75.6 \\
(13)\end{array}$ & $\begin{array}{c}100.9 \pm 73.9 \\
(14)\end{array}$ & $\begin{array}{c}76.5 \pm 28.9 \\
(11)\end{array}$ & $\begin{array}{l}50.4 \pm 11.5 \\
(12)\end{array}$ & $\begin{array}{c}48.8 \pm 14.4 \\
\quad(13)\end{array}$ & $\begin{array}{c}162.6 \pm 69.6 \\
(14)\end{array}$ & $\begin{array}{c}410 \pm 275.8 \\
(12)\end{array}$ \\
\hline SLE & $\begin{array}{c}65.8 \pm 28.7 \\
(16)\end{array}$ & $\begin{array}{c}185.4 \pm 75.1 \\
\quad(17)\end{array}$ & $\begin{array}{l}192.6 \pm 104.9 * \\
(19)\end{array}$ & $\begin{array}{c}105.3 \pm 29.5^{*} \\
(8)\end{array}$ & $\begin{array}{c}55.5 \pm 21.5 \\
(18)\end{array}$ & $\begin{array}{c}56.1 \pm 34.5 \\
(17)\end{array}$ & $\begin{array}{c}145.6 \pm 84.7 \\
(19)\end{array}$ & $\begin{array}{c}564.9 \pm 247.1 \\
(8)\end{array}$ \\
\hline Disease controls & $\begin{array}{c}51.1 \pm 24.6 \\
(8)\end{array}$ & $\begin{array}{c}175.9 \pm 60.8 \\
(8)\end{array}$ & $\begin{array}{c}101.0 \pm 60.6 \\
(8)\end{array}$ & $\begin{array}{c}72.0 \pm 17.5 \\
(6)\end{array}$ & $\begin{array}{c}63.0 \pm 32.1 \\
(8)\end{array}$ & $\begin{array}{c}75.8 \pm 39.3^{\ddagger} \\
(8)\end{array}$ & $\begin{array}{c}167.9 \pm 101.2 \\
(8)\end{array}$ & $\begin{array}{c}546.5 \pm 191.7 \\
(6)\end{array}$ \\
\hline
\end{tabular}

$1 \times 10^{6}$ PBMC were cultured with medium or with PMA and ionomycin for 6, 24, or $48 \mathrm{~h}$, then assessed by indirect immunofluorescence for expression of CD40L and CD25. Mean channel fluorescence (MCF), above that of PBS-BSA/FITC goat anti-mouse Ig-stained cells, was recorded for the gated lymphocyte population. The mean \pm standard deviation of the MCF and the number of individuals studied ( ) is shown for each study population and time point. *MCF CD40L expression was statistically significantly higher for SLE patients after 24- and 48-h culture with PMA and ionomycin when compared with normal subjects $\left(P=0.011\right.$ and 0.038 for 24 and $48 \mathrm{~h}$, respectively) and with disease controls $(P=0.035$ and 0.042$)$. ${ }^{\star} \mathrm{MCF}$ CD25 expression was statistically significantly higher for disease control patients after $6 \mathrm{~h}$ of culture with PMA and ionomycin when compared with normal subjects $(P=0.046)$.

icked using either anti-CD3 $\mathrm{mAb}$, reactive with the signal transducing component of the TCR complex, or PMA (or $\mathrm{PDB}$ ) plus ionomycin, which activate protein kinase $\mathrm{C}$ and increase intracellular $\mathrm{Ca}^{2+}$. These stimuli obviate the need for antigen-specific TCR triggering and bypass the earliest molecular events in TCR-mediated $\mathrm{T}_{\mathrm{h}}$ cell activation.

To assess the level and kinetics of CD40L expression after $\mathrm{T}$ cell activation in patients with SLE, PBMC from SLE patients, disease control patients, and healthy subjects were cultured for 6,24 , or $48 \mathrm{~h}$ with culture medium alone or with PMA and ionomycin, and MCF CD40L and CD25 determined by indirect immunofluorescence and FACS analysis (Figs. 1 and 2 and Table II). While activated cell populations from healthy subjects and disease controls showed high intensity expression (MCF) of CD40L after $6 \mathrm{~h}$ of culture, with a gradual decrease to near baseline at $48 \mathrm{~h}$ of culture, activated lymphocytes from SLE patients continued to demonstrate high level CD 40L at 24 and 48 hours $(P=0.01$ and 0.038 at 24 and $48 \mathrm{~h}$, respectively, when compared with normal subjects, and $P=$ 0.035 and 0.042 at 24 and $48 \mathrm{~h}$, when compared with disease controls) (Fig. 1 and Table II). Representative histograms showing CD3, CD40L, and CD25 expression on untreated and PMA and ionomycin-activated PBMC from a healthy subject and a SLE patient assessed in parallel after 6 and $24 \mathrm{~h}$ of culture are demonstrated in Fig. 2 and illustrate the persistent high level cell surface CD40L at 24 hours in the SLE, but not in the healthy, subject. Of particular interest, MCF above background of CD40L on untreated PBMC was increased in the SLE group, but not statistically different than the normal or disease controls (Table II). Multiparameter fluorescence analysis of paired SLE and control subjects (Fig. 3) showed CD40L on untreated CD4+ SLE T cells, as well as on some CD8+ T cells (not shown), and fluorescence intensity was further increased after in vitro activation, while the normal subject showed high level CD40L expression on CD4+ T cells only after in vitro activation. In contrast to the results with CD40L, the intensity and kinetics of CD25 (Tac) expression were comparable in normal control and SLE subject groups, with MCF gradually increasing over $48 \mathrm{~h}$ of culture (Table II).

Assessment of CD40L expression in terms of the percentage of the mononuclear cells positive, above background fluo- rescence, was also determined and gave comparable results (Figs. 4 and 5). The \% of CD40L + cells in the absence of in vitro activation was increased in some of the SLE patients compared to the normal subjects $(P=0.06)$ (Fig. 4). While these results did not achieve statistical significance, it was of interest that the three SLE patients with the highest baseline CD40L expression had active nephritis or end stage renal disease. CD40L expression after in vitro activation with PMA and ionomycin was significantly greater at $24(P=0.038)$ and $48 \mathrm{~h}(P=0.004)$ in the SLE patients as compared with the normal subjects (Fig. 5). Normal and disease control groups had nearly overlapping patterns of CD40L expression over time when the \% CD40L+ cells at 24 and $48 \mathrm{~h}$ of culture was compared with expression at the optimal $(6 \mathrm{~h})$ time point after initiation of activation, while the SLE group showed a slight increase in CD40L expression from the 6 to the $24 \mathrm{~h}$ time point Fig. 5 B). As CD40L is expressed predominantly on CD4+ T cells, it was possible that differences in the relative composition of the mononuclear cell populations between the SLE and control subject groups accounted for the prolonged kinetics of CD40L expression observed on activated SLE cells. However, the percent of CD4+ mononuclear cells in the SLE patients was not statistically different than that in the normal or disease control groups (data not shown). These data clearly demonstrate that while early after T cell activation by PMA and ionomycin, both SLE and normal $T_{h}$ cells rapidly express high levels of CD40L, in normal subjects, CD40L is quickly downregulated and nearly gone from the cell surface by $48 \mathrm{~h}$. In contrast, SLE $\mathrm{T}$ cells show prolonged high level expression of CD40L for more than $24 \mathrm{~h}$. Moreover, lymphocytes from some SLE patients express some CD40L even in the absence of in vitro activation.

Induction of activation antigen expression on target $B$ cells cultured with CD40L-positive T cells. To evaluate the functional potential of prolonged CD40L expression, the capacity of activated $T$ cells to induce cell surface activation antigen expression on allogeneic target tonsil, Ramos, or CLL B cells was determined. PBMC were cultured with water soluble PDB and ionomycin for 6,24 , or $48 \mathrm{~h}$, the cells were washed, irradiated, and then recultured with Ramos B cell line cells. CD40L and CD25 expression were determined on the activated $T$ cells at each time point (Fig. 6, left panel), and CD23 and B7-1 expres- 
NORMAL

NORMAL PDB/IONOMYCIN
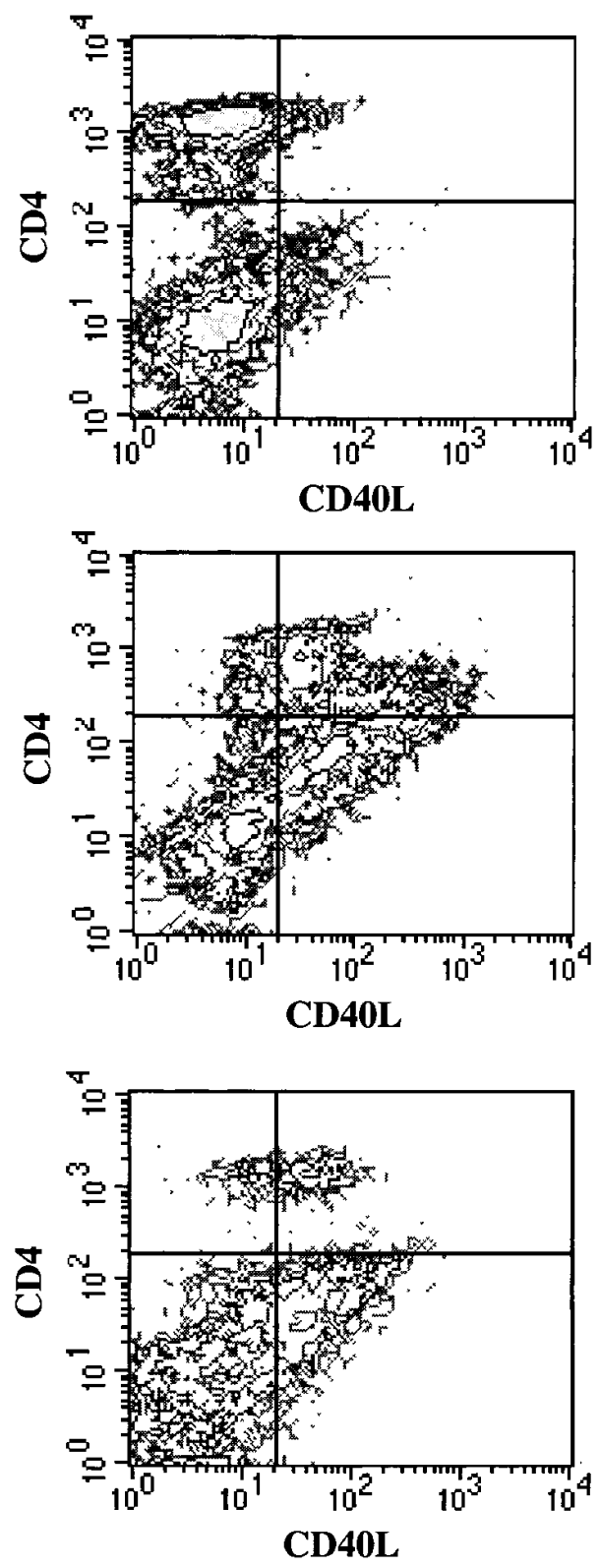

SLE

SLE PDB/IONOMYCIN

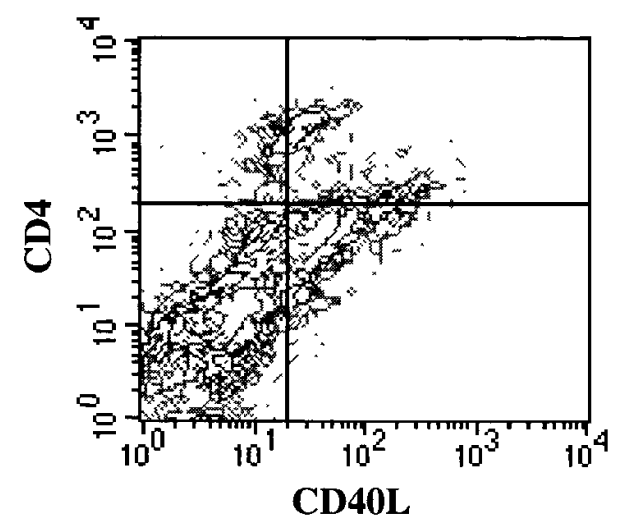

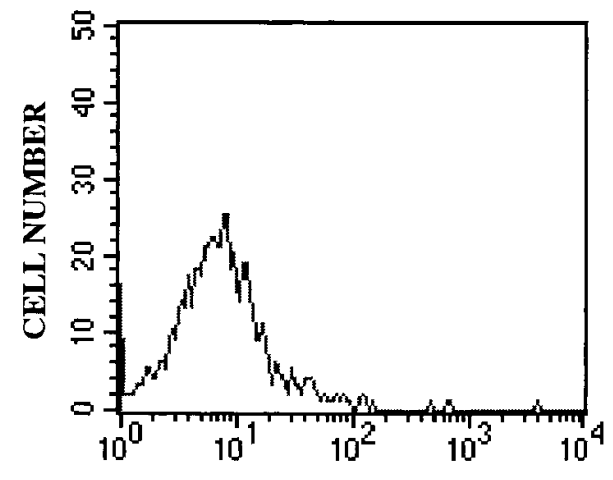

FLUORESCENCE INTENSITY

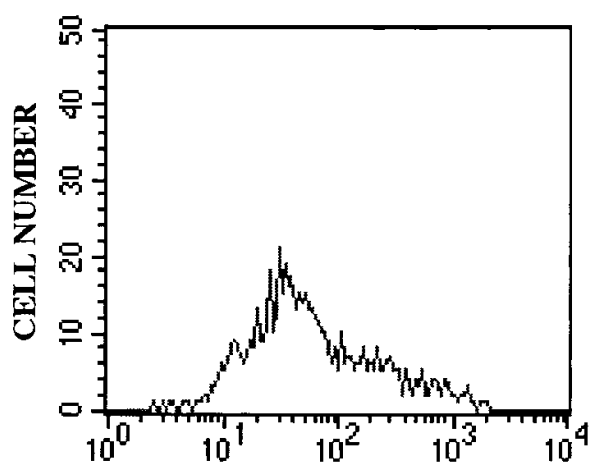

FLUORESCENCE INTENSITY
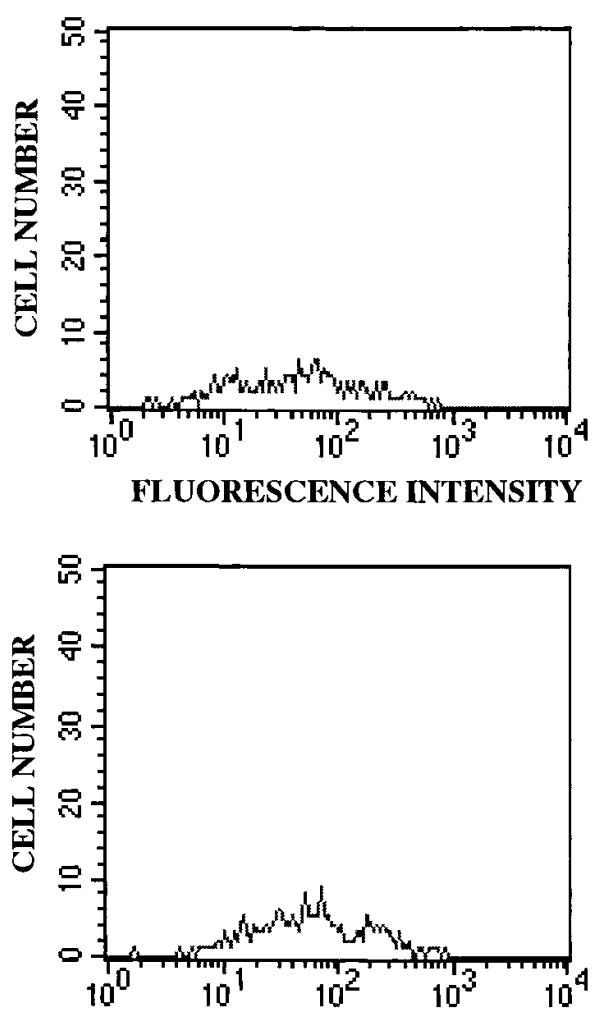

FLUORESCENCE INTENSITY

Figure 3. Expression of CD40L on untreated SLE CD4+ T cells. Normal or SLE PBMC were analyzed by multiparameter flow cytometry after $6 \mathrm{~h}$ of culture with medium alone or with PDB and ionomycin. Propidium iodide positive cells and cells with the scatter properties of monocytes were excluded from the analysis. Left panels show CD4 expression on the Y axis and CD40L expression on the $x$-axis. The horizontal line in the left panels defines the CD4 positive and negative cells, and the vertical line designates the CD40L positive and negative cells. Right panels show histograms indicating the fluorescence intensity of CD40L staining on the CD4+ T cells. 


\section{Baseline CD40 Ligand Expression}

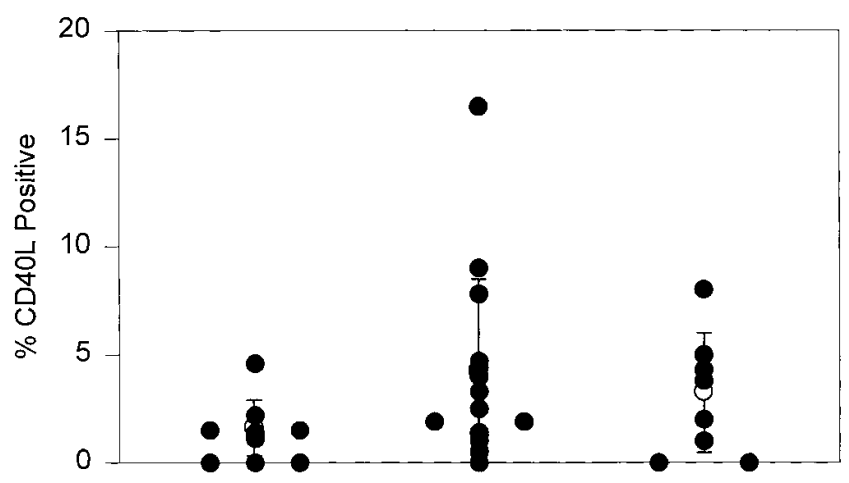

Normal Subjects SLE Patients Disease Controls

Figure 4. Baseline expression of CD40L on PBMC. PBMC from normal subjects, SLE patients, and disease control subjects were analyzed by indirect immunofluorescence for CD40L expression. Results are expressed as the percent of PBMC CD40L + after subtraction of the percent of PBMC positive with goat anti-mouse IgG. The mean (open circle) and standard deviation for each study population are shown.

sion determined on the Ramos B cells cultured for an additional $24 \mathrm{~h}$ with the PBMC preparations (Fig. 6, right panel). Normal PBMC cultures activated with PDB and ionomycin for $6 \mathrm{~h}$, the time point at which CD40L is optimally expressed, in- duced maximal levels of CD23 and B7-1 when cocultured with Ramos B cells, while the 24 and $48 \mathrm{~h}$ activated cultures induced less CD23 and B7-1 on the cocultured Ramos B cells (Fig. 6, right panel). Comparable data were obtained after culture of activated PBMC with tonsillar B cells (not shown). Thus, capacity of the activated $\mathrm{PBMC}$ populations to induce expression of CD23 and B7-1 on target B cells correlated with the kinetics of $\mathrm{T}_{\mathrm{h}}$ cell expression of $\mathrm{CD} 40 \mathrm{~L}$, rather than expression of CD25.

To further implicate CD40L-CD40 interactions in the induction of $\mathrm{B}$ cell activation antigens in the PDB and ionomycin-treated PBMC culture system, the capacity of a mAb specific for human CD40L to inhibit the induction of B cell CD23 was studied (Fig. 7). While anti-CD40L mAb did not alter expression of the pan-B cell marker CD19 on a CLL target B cell population cultured with $24 \mathrm{~h}$ PDB and ionomycin-activated PBMC, CD23 expression was inhibited nearly to baseline levels by inclusion of the anti-CD40L mAb in the activated PBMC/CLL B cell culture. These experiments suggest that the functional consequences of CD40L expression on activated $T_{h}$ cells for $\mathrm{B}$ cell activation can be measured by the induction of $B$ cell activation antigens on cocultured target $B$ cells. They do not, however, rule out a contribution of $\mathrm{T}$ cell-derived cytokines, such as interleukin 4 or tumor necrosis factor $\alpha$, to the level of B cell activation antigens expressed.

Augmented expression of CD80 (B7-1) on target B cells cultured with PDB and ionomycin-activated SLE PBMC. To assess whether the prolonged expression of CD40L on activated SLE $\mathrm{T}_{\mathrm{h}}$ cells might result in augmented help for B cell activa-
A.

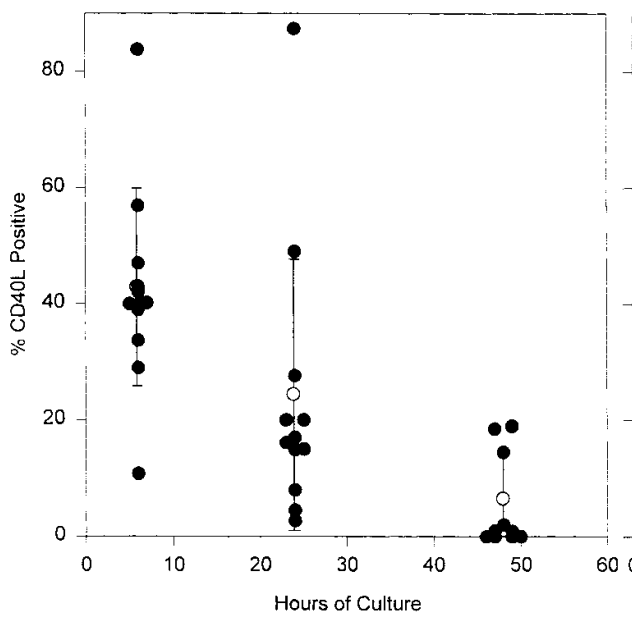

B.

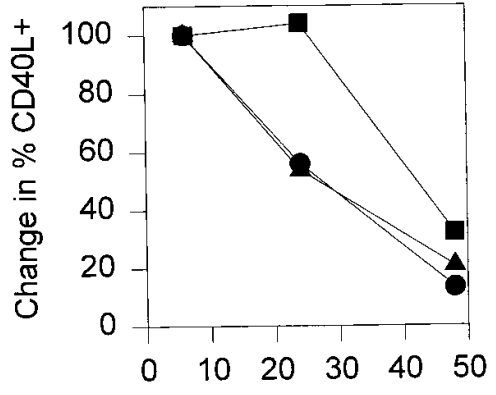

Hours of Culture
SLE Patients
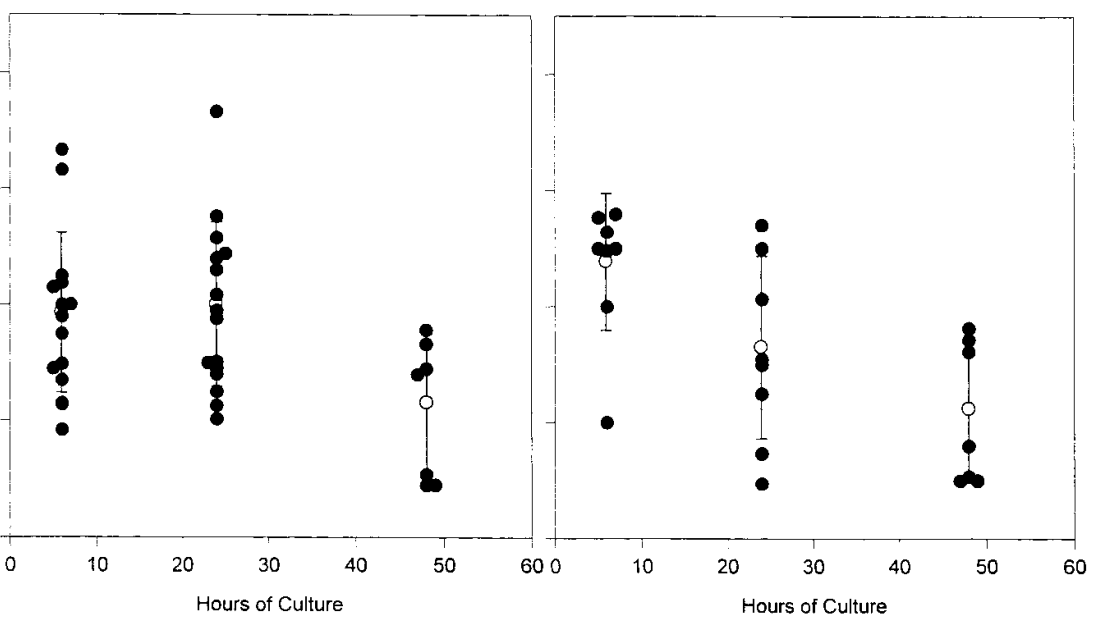

Figure 5. Kinetics of CD40L expression, shown as percent of $\mathrm{PBMC}+$, after in vitro activation. (A) PBMC from normal subjects (left panel), SLE patients (middle panel), and disease control subjects (right panel) were cultured for 6,24 , or $48 \mathrm{~h}$ with medium alone or with PMA and ionomycin and then assessed by indirect immunofluorescence analysis and FACS for CD40L expression. Results are expressed as percent of the gated activated lymphocyte population positive for CD40L (after subtracting background fluorescence). The mean (open circle) and standard deviation for each study population at each time point are shown. $(B)$ The mean for each subject group of percent CD40L + of in vitro activated $\mathrm{PBMC}$, when compared with percent CD40L + at $6 \mathrm{~h}$ (time point of maximum expression, considered $100 \%$ ), is shown at 24 and 48 h of culture. Normal subjects are shown as closed circles, SLE patients as closed squares, and disease controls as closed triangles. 
T Cell Activation Antigen Expression

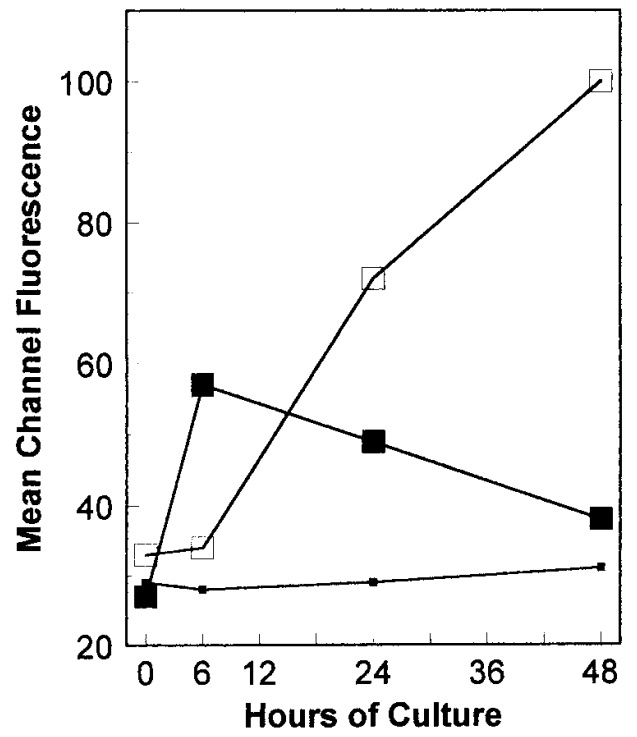

B Cell Activation Antigen Expression

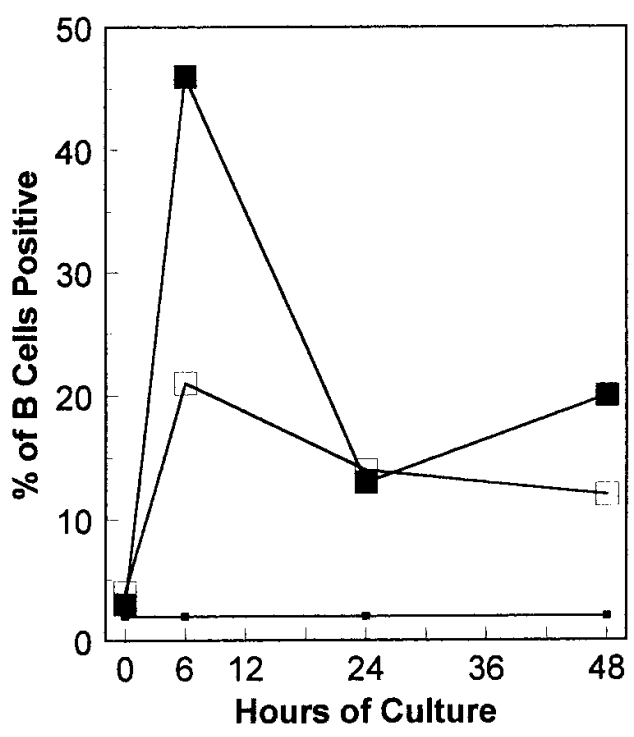

Figure 6. CD23 and B7-1 are maximally expressed on target $\mathrm{B}$ cells cultured with 6 hour PDB and ionomycin-activated PBMC. PBMC from a normal subject were cultured for $0,6,24$ or $48 \mathrm{~h}$ with PDB and ionomycin. At each time point, an aliquot of the PBMC was stained for background fluorescence (left panel, closed small squares), CD40L (left panel, closed large squares), or CD25 (left panel, open large squares). The activated PBMC were washed, irradiated with 1000R from a Cesium source, and $1 \times$ $10^{6}$ cells added to $0.5 \times$ $10^{6}$ Ramos B cell line

cells. After 24 additional hours of culture, the Ramos B cells were assessed for background fluorescence (right panel, closed small squares), $\mathrm{CD} 23$ (right panel, closed large squares), or B7-1 (right panel, open large squares).

tion, PBMC from healthy subjects and SLE patients were cultured for $24 \mathrm{~h}$ with medium or with PDB and ionomycin, the cells washed, irradiated, and then cocultured for an additional $24 \mathrm{~h}$ with Ramos B cell line cells or with, in one experiment,

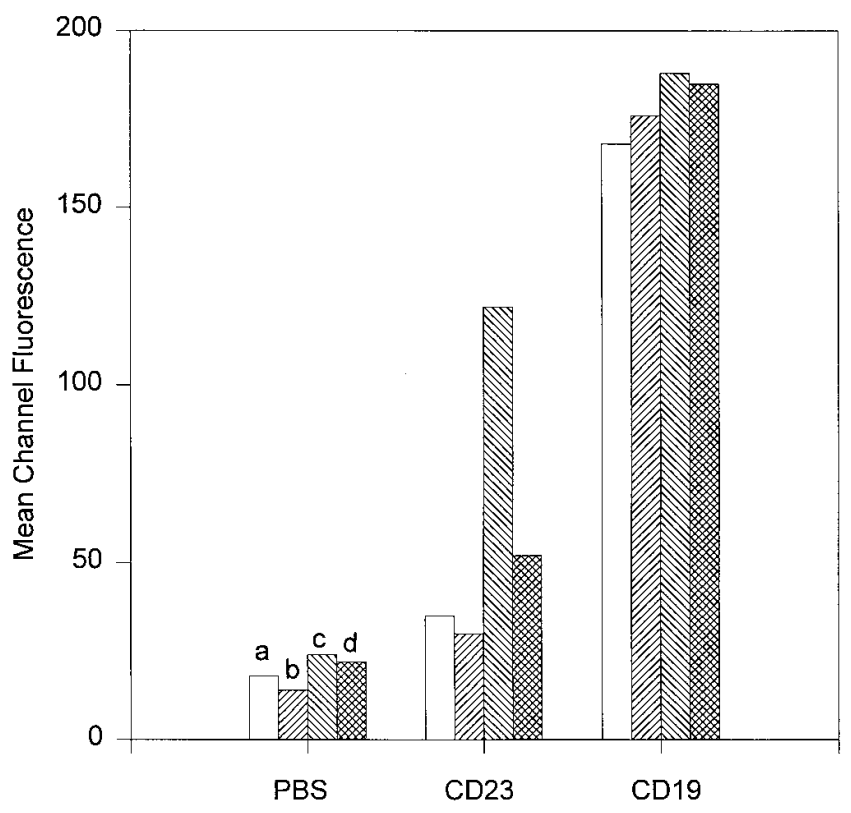

Figure 7. $\mathrm{mAb}$ reactive with $\mathrm{CD} 40 \mathrm{~L}$ inhibits the induction of $\mathrm{B}$ cell $\mathrm{CD} 23$ expression by PDB and ionomycin-activated PBMC. Normal PBMC were cultured for $24 \mathrm{~h}$ with medium or with PDB and ionomycin, the cells washed, irradiated, and then recultured with target B cells from a CLL patient. After an additional $48 \mathrm{~h}$ of culture, CLL B cells were assessed by indirect immunofluorescence for background fluorescence (PBS), CD23, or CD19, as indicated. For each staining assay, culture conditions included $(a)$ B cells plus PBMC; $(b)$ B cells plus PBMC, in the presence of $10 \mathrm{ug} / \mathrm{ml}$ mouse IgG anti-human CD40L mAb; (c) B cells plus PBMC activated with $\mathrm{PDB}$ and ionomycin; and $(d) \mathrm{B}$ cells plus PBMC activated with PDB and ionomycin, in the presence of anti-CD40L mAb. tonsil B cells (Figs. 8 and 9). The mean data derived from 5 experiments show that normal PBMC activated in vitro for $24 \mathrm{~h}$ increased the MCF of B cell B7-1 by 4 channels, when compared with untreated normal PBMC, while SLE PBMC, activated in vitro for $24 \mathrm{~h}$, induced an increase of 15 channels B7-1 expression on target B cells when compared with untreated SLE PBMC. The MCF of B7-1 induced by the activated SLE PBMC was significantly greater than the low level B7-1 induced by activated normal PBMC $(P=0.013)$. Cytofluorograph histograms of Ramos B cells cultured with PBMC from a normal subject and a SLE patient analyzed in this system are shown in Fig. 9, with the activated SLE cells inducing high level B7-1 expression on the target Ramos B cells. These data suggest that the level of CD40L that persists on the SLE $\mathrm{T}_{\mathrm{h}}$ cell surface after $24 \mathrm{~h}$ of in vitro activation, a time point at which normal $T_{h}$ cells are rapidly modulating their CD40L, may be functionally significant and contribute to excessive $B$ cell activation, as measured by B7-1 expression.

\section{Discussion}

A consistently observed manifestation of immune dysfunction in SLE is the hyperactivity of the humoral immune system, both in vitro and in vivo. In vitro, SLE B cells are noted to be enlarged and of lower density than normal B cells; they express some B cell activation antigens in the absence of experimental stimulation; and they are hyperresponsive to T cell-derived cytokines $(41,42)$. In vivo, the SLE humoral immune system is characterized by hypergammaglobulinemia, immune complex formation, and complement system activation (43). While highly specific autoantigen-driven responses, particularly those directed at protein and nucleic acid components of intracytoplasmic and intranuclear particles, are characteristic of the antibodies produced in patients with $\operatorname{SLE}(1,3,4)$, recent evidence suggests that determinant spreading of the antibody response from an early narrow range of specificities to a later broad range of specificities may be operative (44-47). 


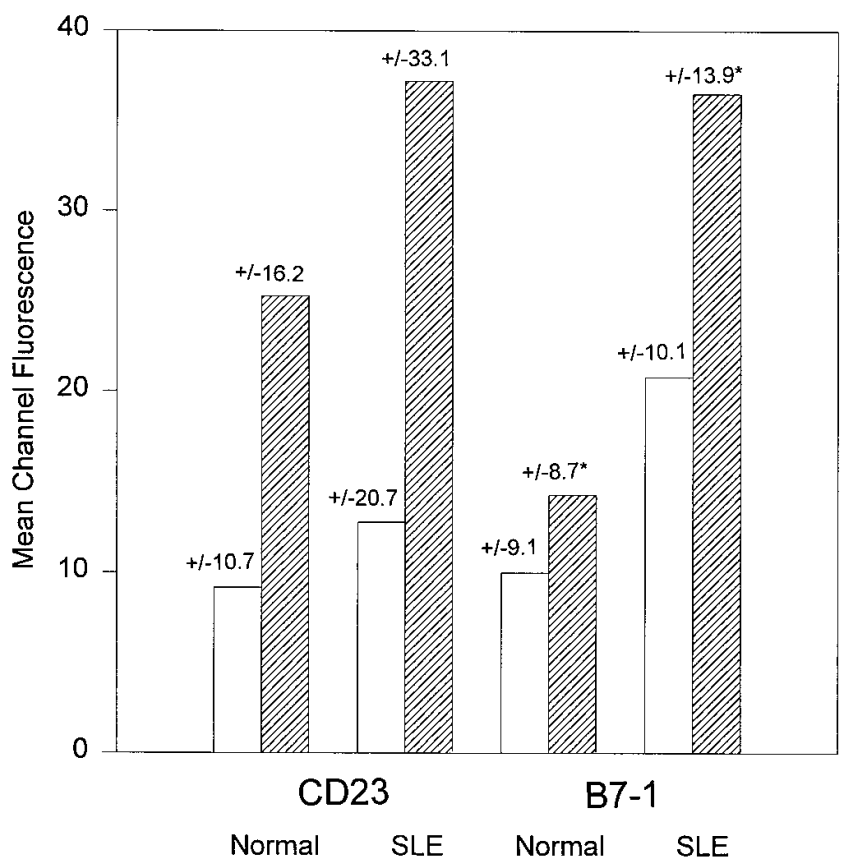

Figure 8. Induction of B7-1 expression on target B cells cultured with $24 \mathrm{~h}$-activated SLE PBMC. Five normal and five SLE PBMC preparations were incubated for $24 \mathrm{~h}$ with medium (open bars) or with PDB and ionomycin (hatched bars), washed, irradiated, and then recultured with target B cells (Ramos B cell line cells in four experiments and tonsillar B cells in one experiment) for an additional $24 \mathrm{~h}$. CD23 and B7-1 expression on the target B cells were assessed by indirect immunofluorescence and expressed as MCF, after subtraction of background fluorescence. Results shown are the mean MCF values ( \pm standard deviation) for the B cells activated with normal control or SLE PBMC. A statistically significant difference (*) was observed between B7-1 expression induced by activated normal PBMC and activated SLE PBMC $(P=0.01)$.

To investigate $T_{h}$ cell-dependent $B$ cell activation in SLE, and to understand the mechanisms by which a presumably well-focused early autoreactive immune response might generate a more generalized humoral response of persistent high magnitude, we studied the regulation of CD40L expression on untreated and in vitro-activated SLE PBMC. In an effort to observe the phenotypic change and functional response of SLE $\mathrm{T}_{\mathrm{h}}$ cells to a successful activating stimulus, we chose to stimulate the PBMC with PMA or PDB plus ionomycin, thus bypassing the requirement for successful TCR ligation. While this stimulus is unquestionable artificial, it allowed us to effectively compare normal and SLE $\mathrm{T}_{\mathrm{h}}$ cell responses in the system best studied by others who have investigated the regulation of CD40L expression.

Our data demonstrate that after in vitro activation of PBMC with PMA and ionomycin, T cells from normal subjects, SLE patients, and patients with systemic inflammatory disease show comparable high level expression of CD40L at $6 \mathrm{~h}$ of culture and similar kinetics of CD25 expression at all time points studied. Importantly, SLE T cells, but not T cells from the healthy or disease control groups, showed persistent near maximal expression of CD40L at $24 \mathrm{~h}$ of culture, and continued expression of CD40L after 48 hours of culture. CD40L expression was significantly prolonged in SLE whether assessed in terms of MCF or as percent CD40L+ PBMC, and
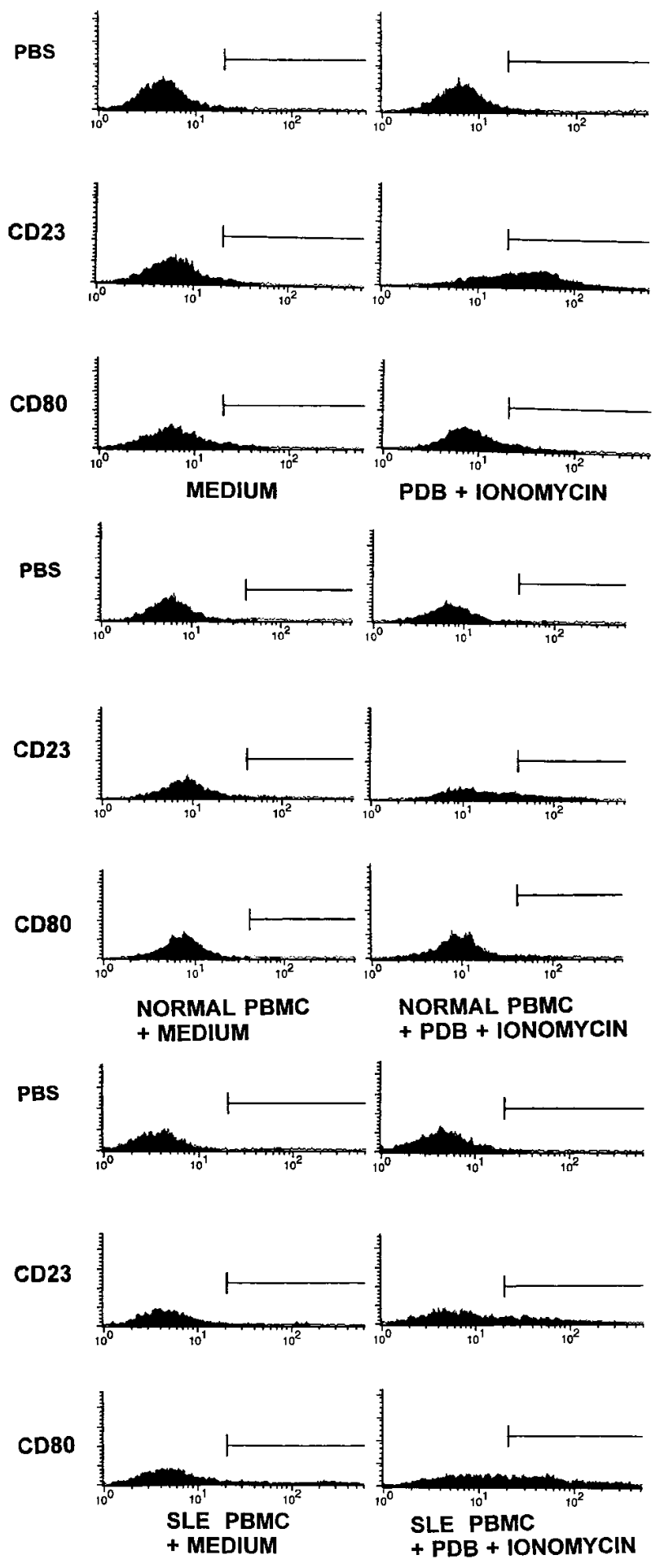

Figure 9. Induction of activation antigen expression on Ramos B cells. Ramos B cells were analyzed by indirect immunofluorescence for expression of CD23 and CD80 (B7-1) after 24-h culture with medium alone (top left) or PDB and ionomycin (top right), with normal PBMC precultured for $24 \mathrm{~h}$ with medium (middle left) or PDB and ionomycin (middle right), or with SLE PBMC precultured with medium (lower left) or with PDB and ionomycin (lower right). 
was not attributable to differences in the proportion of CD4+ cells present. Also striking was the baseline expression of CD40L on untreated PBMC from some SLE patients. Preliminary analysis suggests that in addition to CD4+ T cell expression of CD40L, a population of CD8+ SLE T cells may also bear cell surface CD40L in the absence of in vitro activation in some patients (data not shown). While there was no apparent correlation between the kinetics of CD40L expression with disease activity in the SLE patients (see Table I), many of the patients did have active lupus at the time of study. Prolonged CD40L expression after in vitro activation may reflect chronic in vivo polyclonal $\mathrm{T}$ cell activation, likely attributable to $\mathrm{T}$ cell triggering by a spectrum of autoantigens. The mechanism responsible for the observed phenotype may be similar to that of the persistent cell surface CD40L on short term $\mathrm{T}$ cell lines from normal subjects that have been repeatedly retriggered through the TCR in vitro (data not shown). Disease activity may be more closely reflected in the baseline CD40L than in the kinetics of expression, as the three SLE patients with the highest CD40L expression in the absence of in vitro activation had active or end stage renal disease. Careful study and clinical characterization of additional patients will be necessary to support this possibility. A potential effect of corticosteroid treatment on CD40L expression is difficult to rule out. Most of the SLE patients, as well as some of the disease control patients, were receiving corticosteroid or other potentially immunosuppressive treatment at the time of study, although none was receiving cyclosporin $\mathrm{A}$, an agent known to inhibit the expression of CD40L on $\mathrm{T}_{h}$ cells activated with PMA and ionomycin (38).

Definition of the cellular mechanisms that account for increased and prolonged CD40L expression in SLE will be a focus of our future studies. We favor the prediction that prolonged CD40L expression reflects persistent and polyclonal activation of $T_{h}$ cells in the SLE patients with active disease, or impaired downregulation of CD40L, rather than an intrinsic abnormality in the CD40L molecule. SLE $\mathrm{T}_{\mathrm{h}}$ cells may be enriched in memory $\mathrm{T}$ cells, which may have altered kinetics of CD40L expression when compared with naive $T_{h}$ cells. Memory cells have recently been reported to rapidly express CD40L within minutes of in vitro activation, although in contrast to our results, in that study the memory cells lost their cell surface CD40L within hours (48). Altered levels of cytokines in patients with SLE may affect CD40L expression, as has been reported in the normal murine system (37). Yellin et al. have found a role for B cell CD40 binding to T cell CD40L in the downregulation of CD40L and its clearance from the $T_{h}$ cell surface (39). Analysis of SLE B cell CD40 expression and function may elucidate the basis of altered SLE T cell CD40L kinetics. As B cells have recently been reported to express low level CD40L after activation (49), B cells may also contribute to either baseline or prolonged expression of CD40L in SLE.

The most important issue to be addressed is the functional significance of prolonged CD40L expression for SLE B cell activity and the generation of the autoantibody repertoire. To begin to investigate this question, we established an in vitro assay of $T_{h}$ cell-mediated induction of target $B$ cell activation antigen expression, similar to our assays that have measured direct $\mathrm{T}$ cell help mediated by $\mathrm{T}$ cell clones or anti-CD3 $\mathrm{mAb}$ activated PBMC (50-53). Tonsillar B cells, CLL B cells, or the Ramos Burkitt's lymphoma B cell line served as responder cells to assess the functional effect of $T_{h}$ cell CD40L expression on B cell CD40 ligation. CD23 and CD80 (B7-1) are induced after B cell signaling through CD40 $(30-31,54)$. While some $\mathrm{T}$ cell-derived cytokines can also stimulate the expression of these B cell activation molecules, ligation of CD40 may be the most significant physiologic stimulus (54). The capacities of $24 \mathrm{~h}$-activated SLE and normal PBMC to induce CD23 and CD80 on target B cells were compared. At that time point, the level of CD40L on normal T cells was diminished from its peak, while SLE T cells still expressed high levels of CD40L. While the activated cell preparations from healthy subjects showed modest induction of CD80 on target B cells, activated SLE cell preparations stimulated statistically significantly higher levels of B cell CD80. These results suggest that the prolonged high level CD40L on activated SLE $\mathrm{T}_{h}$ cells may have functional consequences for autologous $\mathrm{B}$ cell activity, as was observed for the allogeneic target B cells used in our assay.

Among models of lymphocyte immunoregulation that have been applied to the analysis of autoantibody production are those that implicate intramolecular-intrastructural determinant spreading of antibody responses (44-47). The capacity of a B cell to specifically bind and process a complex particle can sometimes result in the activation of $T_{h}$ cells specific for cryptic epitopes within that particle and the sequential generation of a range of antibody specificities reactive with components of the particle. While our experiments do not address the mechanisms through which autoantigen-specific T cells become activated in SLE, the prolonged expression of CD40L that we have observed may contribute to the maturation and generalization of $T_{h}$ cell-dependent autoantibody secretion. Through the augmentation of B cell CD80 expression, CD40L may also contribute to inappropriate CD28 signaling and the activation of autoreactive $\mathrm{T}$ cells in the presence of adequate autoantigen (55).

In view of the striking and long lasting therapeutic effect of anti-CD40L mAb in a murine model of chronic graft versus host disease, clinically similar to SLE, and in the (SWR $\times$ NZB)F1 murine lupus model $(56,57)$, our results in patients with SLE support the CD40L-CD40 molecular pair as an important potential target for therapy in human disease.

\section{Acknowledgments}

The authors thank Drs. Seth Lederman and Michael Yellin for providing the $5 \mathrm{c} 8$ anti-CD40L mAb, Andrew Beavis for assistance with multiparameter flow cytometry, and Venus Te Eng Fo for assistance in the preparation of the manuscript.

This work was supported by the National Institutes of Health grants P50 AR42588 (SCOR) and AI28367 and by the Merrill Lynch Foundation.

\section{References}

1. Hardin, J.A. 1986. The lupus autoantigens and the pathogenesis of systemic lupus erythematosus. Arthritis Rheum. 29:457-460.

2. Gharavi, A., J.L. Chu, and K.B. Elkon. 1988. Autoantibodies in systemic lupus erythematosus are not due to random polyclonal B cell activation. Arthritis Rheum. 31:1337-1345.

3. Mohan, C., S. Adams, V. Stanik, and S.K. Datta. 1993. Nucleosome. A major immunogen for pathogenic autoantibody-inducing $\mathrm{T}$ cells of lupus. $J$. Exp. Med. 177:1367-1381.

4. Burlingame, R.W., M.L. Boey, G. Starkebaum, and R.L. Rubin. 1994. The central role of chromatin in autoimmune responses to histones and DNA in SLE. J. Clin. Invest. 94:184-192. 
5. Radic, M.Z., and M. Weigert. 1994. Genetic and structural evidence for antigen selection of anti-DNA antibodies. Annu. Rev. Immunol. 12:487-520.

6. Pham, B., N.L. Prin, D. Gosset, P.Y. Hatron, B. Devulder, A. Capron, and J.P. Dessaint. 1989. T lymphocyte activation in systemic lupus erythematosus analyzed by proliferative response to nucleoplasmic proteins on nitrocellulose immunoblots. Clin. Exp. Immunol. 77:168-174.

7. Hoffman, R.W., Y. Takeda, G.C. Sharp, D.R. Lee, D.L. Hill, H. Kaneoka and C.W. Caldwell. 1993. Human T cell clones reactive against U-small nuclear ribonucleoprotein autoantigens from connective tissue disease patients and healthy individuals. J. Immunol. 151:6460-6467.

8. Okubo, M., K. Yamamoto, T. Kato, N. Matsuura, T. Nishimaki, R. Kasukawa, K. Ito, Y. Mizushima, and K. Nishioka. 1993. Detection and epitope analysis of autoantigen-reactive $\mathrm{T}$ cells to the U1-small nuclear ribonucleoprotein A protein in autoimmune disease patients. J. Immunol. 151:1108-1115.

9. O'Brien, R.M., D.S. Cram, R.L. Coppel, and L.C. Harrison. 1990. T-cell epitopes on the 70-kDa protein of the (U1)RNP complex in autoimmune rheumatologic disorders. J. Autoimmun. 3:747-757.

10. Crow, M.K., G. DelGiudice-Asch, J.B. Zehetbauer, J.L. Lawson, N. Brot, H. Weissbach, and K.B. Elkon. 1994. Autoantigen-specific T cell proliferation induced by the ribosomal $\mathrm{P} 2$ protein in patients with systemic lupus erythematosus. J. Clin. Invest. 94:345-352.

11. Bretscher, P., and M. Cohn. 1970. A theory of self-nonself discrimination. Science (Wash. DC). 169:1042-1049.

12. Bretscher, P. 1992. The two-signal model of lymphocyte activation twenty-one years later. Immunol. Today. 13:74-76.

13. Lederman, S., M.J. Yellin, A. Krichevsky, J. Belko, J.J. Lee, and L. Chess. 1992. Identification of a novel surface protein on activated CD4+ T cells that induces contact dependent B cell differentiation. J. Exp. Med. 175:10911101.

14. Hollenbaugh, D., I. Grosmire, C. Kullas, N. Chalupny, S. BraeschAndersen, R. Noelle, I. Stamenkovic, J. Ledbetter, and A. Aruffo. 1992. The human T cell antigen gp39, a member of the TNF gene family, is a ligand for the CD40 receptor: Expression of a soluble form of gp39 with B cell costimulatory activity. EMBO (Eur. Mol. Biol. Organ.) J. 11:4314-4321.

15. Spriggs, M.K., R.J. Armitage, L. Strockbine, K.N. Clifford, B.M. Macduff, T.A. Sato, C.R. Maliszewski, and W.C. Fanslow. 1992. Recombinant human CD40 ligand stimulates B cell proliferation and immunoglobulin E secretion. J. Exp. Med. 176:1543-1550.

16. Banchereau, J., F. Bazan, D. Blanchard, F. Briere, J.P. Galizzi, C. van Kooten, Y.J. Liu, F. Rousset, and S. Saeland. 1994. The CD40 antigen and its ligand. Ann Rev. Immunol. 12:881-922.

17. Lederman, S., M.J. Yellin, G. Inghirami, J.J. Lee, D.M. Knowles, and L. Chess. 1992. Molecular interactions mediating T-B lymphocyte collaboration in human lymphoid follicles: roles of T-B activating molecule (5c8 antigen) and CD40 in contact-dependent help. J. Immunol. 149:3817-3826.

18. Shapira, S.K., D. Vercelli, H.H. Jabara, S.M. Fu, and R.S. Geha. 1992. Molecular analysis of the induction of immunoglobulin E synthesis in human B cells by interleukin 4 and engagement of CD40 antigen. J. Exp. Med. 175:289292.

19. Splawski, J.B., S.M. Fu, and P.E. Lipsky. 1993. Immunoregulatory role of CD40 in human B cell differentiation. J. Immunol. 150:1276-1285.

20. Grabstein, K.H., C.R. Maliszewski, K. Shanebeck, T.A. Sato, M.K. Spriggs, W.C. Fanslow, and R.J. Armitage. 1993. The regulation of T cell-dependent antibody formation in vitro by CD40 ligand and IL-2. J. Immunol. 150: 3141-3147.

21. Nonoyama, S., D. Hollenbaugh, A. Aruffo, J.A. Ledbetter, and H.D. Ochs. 1993. B cell activation via CD40 is required for specific antibody production by antigen-stimulated human B cells. J. Exp. Med. 178:1097-1102.

22. Allen, R.C., R.J. Armitage, M.E. Conley, H. Rosenblatt, N.A. Jenkins, N.G. Copeland, M.A. Bedell, S. Edelhoff, C.M. Disteche, D.K. Simoneaux, W.C. Fanslow, J.W. Belmont, and M.K. Spriggs. 1993. CD40 ligand gene defects responsible for X-linked hyper-IgM syndrome. Science (Wash. DC). 259: 990-993.

23. Korthauer, U., D. Graf, H.W. Mages, F. Briere, M. Padayachee, S. Malcolm, A.G. Ugazio, L.D. Notarangelo, R.J. Levinsky, and R.A. Kroczek. 1993. Defective expression of T-cell CD40 ligand causes X-linked immunodeficiency with hyper-IgM. Nature (Lond.). 361:539-541.

24. DeSanto, J.P., Y.Y. Bonnefoy, J.F. Gauchat, A. Fischer, and G. de Saint Basile. 1993. CD40 ligand mutations in X-linked immunodeficiency with hyperIgM. Nature (Lond.). 361:542-543.

25. Aruffo, A., M. Farrington, D. Hollenbaugh, X. Li, A. Milatovich, S. Nonoyama, J. Bajorath, S. Grosmaire, R. Stenkamp, M. Neubauer, R.L. Roberts, R.J. Noelle, J.A. Ledbetter, U. Francke, and H.D. Ochs. 1993. The CD40 ligand, gp39, is defective in activated T cells from patients with X-linked hyperIgM syndrome. Cell. 72:292-300.

26. Ramesh, N., R. Fuleihan, V. Ramesh, S. Lederman, M.J. Yellin, S. Sharma, L. Chess, F.S. Rosen, and R.S. Geha. 1993. Deletions in the ligand for CD40 in X-linked immunoglobulin deficiency with normal or elevated IgM (HIGMX-1). Int. Immunol. 5:769-773.

27. Fuleihan, R., N. Ramesh, R. Loh, H. Jabara, F.S. Rosen, T. Chatila, S.M. Fu, I. Stamenkovic, and R.S. Geha. 1993. Defective expression of the CD40 ligand in X chromosome-linked immunoglobulin deficiency with normal or elevated IgM. Proc. Natl. Acad. Sci. USA. 90:2170-2173.

28. Conley, M.E., M. Larche, V.R. Bonagura, A.R. Lawton III, R.H. Buckley, S.M. Fu, E. Coustan-Smith, H.G. Herrod, and D. Campana. 1994. Hyper IgM syndrome associated with defective CD40-mediated B cell activation. $J$. Clin. Invest. 94:1404-1409.

29. Barrett, T.B., G. Shu, and E.A. Clark. 1991. CD40 signaling activates CD11a/CD18 (LFA-1)-mediated adhesion in B cells. J. Immunol. 146:17221729.

30. Saeland, S., V. Duvert, I. Moreau, and J. Banchereau. 1993. Human B cell precursors proliferate and express CD23 after CD40 ligation. J. Exp. Med. 178:113-120.

31. Yellin, M.J., J. Sinning, L.R. Covey, W. Sherman, J.J. Lee, E. GlickmanNir, K.C. Sippel, J. Rogers, A.M. Cleary, M. Parker, L. Chess, and S. Lederman. 1994. T lymphocyte T cell-B cell-activating molecule/CD40-L molecules induce normal B cells or chronic lymphocytic leukemia B cells to express CD80 (B7/BB-1) and enhance their costimulatory activity. J. Immunol. 153:666-674.

32. Schattner, E., K.B. Elkon, J. Tumang, M.K. Crow, and S.M. Friedman. 1995. CD40 ligation induces Apo-1/Fas expression on human B lymphocytes and facilitates apoptosis through the Apo-1/Fas pathway. J. Exp. Med. 182: $1557-1565$.

33. Boussiotis, V.A., L.M. Nadler, J.L. Strominger, and A.E. Goldfeld. 1994. Tumor necrosis factor $\alpha$ is an autocrine growth factor for normal human B cells. Proc. Natl. Acad. Sci. 91:7007-7011.

34. Renshaw, B.R., B.R. Fanslow, R.J. Armitage, K.A. Campbell, D. Lig gitt, B. Wright, B.L. Davison, and C.R. Maliszewski. 1994. Humoral immune responses in CD40 ligand-deficient mice. J. Exp. Med. 180:1889-1900.

35. Castigli, E., F.A. Alt, L. Davidson, A. Bottaro, E. Mizoguchi, A. Bhan, and R.S. Geha. 1994. CD40-deficient mice generated by recombination-activating gene-2-deficient blastocyst complementation. Proc. Natl. Acad. Sci. USA. 91:12135-12139.

36. Lederman, S., M.J. Yellin, A.M. Cleary, A. Pernis, G. Inghirami, L.E. Cohn, L.R. Covey, J.J. Lee, P. Rothman, and L. Chess. 1994. T-BAM/CD40-L on helper T lymphocytes augments lymphokine-induced B cell Ig isotype switch recombination and rescues B cells from programmed cell death. J. Immunol. 152:2163-2171.

37. Roy, M., T. Waldschmidt, A. Aruffo, J.A. Ledbetter, and R.J. Noelle. 1993. The regulation of the expression of gp39, the CD40 ligand, on normal and cloned CD4+ T cells. J. Immunol. 151:2497-2510.

38. Fuleihan, R., N. Ramesh, A. Horner, D. Ahern, P.J. Belshaw, D.G. Alberg, I. Stamenkovic, W. Harmon, and R.S. Geha. 1994. Cyclosporin A inhibits CD40 ligand expression in T lymphocytes. J. Clin. Invest. 93:1315-1320.

39. Yellin, M.J., K. Sippel, G. Inghirami, L.R. Covey, J.J. Lee, J. Sinning, E.A. Clark, L. Chess, and S. Lederman. 1994. CD40 molecules induce downmodulation and endocytosis of T cell surface T cell-B cell activating molecule/ CD40-L. J. Immunol. 152:598-608.

40. Tan, E.M., A.S. Cohen, J.P. Fries, A.T. Masi, D.J. McShane, N.F. Rothfield, J.G. Schaller, N. Talal, and R.J. Winchester. 1982. The 1982 revised crite ria for the classification of systemic lupus erythematosus. Arthritis Rheum. 25: 1271-1277.

41. Glinski, W., D.R. Gershwin, D.R. Budman, and A.D. Steinberg. 1976. Study of lymphocyte subpopulations in normal humans and patients with systemic lupus erythematosus by fractionation of peripheral blood lymphocytes on a discontinuous Ficoll gradient. Clin. Exp. Immunol. 26:228-238.

42. Veda, Y., T. Sakane, and T. Tsunematsu. 1989. Hyperreactivity of activated B cells to B cell growth factor in patients with systemic lupus erythematosus. J. Immunol. 143:3988-3983.

43. Krishnan, C., and M.H. Kaplan. 1967. Immunopathologic studies of systemic lupus erythematosus. II. Antinuclear reaction of gammaglobulin eluted from homogenates and isolated glomeruli of kidneys from patients with lupus nephritis. J. Clin. Invest. 46:569-579.

44. Lehmann, P.V., T. Forsthuber, A. Miller, and E.E. Sercarz. 1992. Spreading of T-cell autoimmunity to cryptic determinants of an autoantigen. Nature (Lond.). 358:155-157.

45. Fatenjad, S., W. Brooks, A. Schwartz, and J. Craft. 1994. Pattern of antismall nuclear ribonucleoprotein antibodies in MRL/Mp-lpr/lpr mice suggests that the intact U1 snRNP particle is their autoimmunogenic target. J. Immunol. 152:5523-5531.

46. Topfer, F., T. Gordon, and J. McCluskey, 1995. Intra- and intermolecular spreading of autoimmunity involving the nuclear self-antigens La (SS-B) and Ro (SS-A). Proc. Natl. Acad. Sci. USA. 92:875-879.

47. James, J.A., T. Gross, R.H. Scofield, and J.B. Harley. 1995. Immunoglobulin epitope spreading and autoimmune disease after peptide immunization: $\mathrm{Sm}$ B/B'-derived PPPGMRPP and PPPGIRGP induce spliceosome autoimmunity. J. Exp. Med. 181:453-461.

48. Casamayor-Palleja, M., M.Khan, I.C. MacKennan. 1995. A subset of $\mathrm{CD} 4+$ memory $\mathrm{T}$ cells contains preformed CD40 ligand that is rapidly but transiently expressed on their surface after ligation through the T cell receptor complex. J. Exp. Med. 181:1293-1301.

49. Grammer, A.C., M.C. Bergman, Y. Miura, K. Fujita, L.S. Davis, and P.E. Lipsky. 1995. The CD40 ligand expressed by human B cells costimulates B cell responses. J. Immunol. 154:4996-5010.

50. Crow, M.K., J.A. Jover, and S.M. Friedman. 1986. Direct T helper-B cell 
interactions induce an early B cell activation antigen. J. Exp. Med. 164:17601772 .

51. Jover, J.A., E.K. Chartash, B. Kushner, S.M. Friedman, and M.K. Crow. 1989. T helper cell-induced CD23 (BLAST-2) expression: An activation marker for the high density fraction of human B cells. Clin. Immunol. Immunopathol. 53:99-112.

52. Crow, M.K., B. Kushner, J.A. Jover, S.M. Friedman, S.E. Mechanic, and W. Stohl. 1989. Human peripheral blood T helper cell-induced B cell activation results in B cell surface expression of the CD23 (BLAST-2) antigen. Cell Immunol. 121:99-112.

53. Tumang, J.R., D.N. Posnett, B.C. Cole, M.K. Crow, and S.M. Friedman. 1990. Helper T cell-dependent human B cell differentiation mediated by a my- coplasmal superantigen bridge. J. Exp. Med. 171:2153-2158.

54. Roy, M., A. Aruffo, J. Ledbetter, P. Linsley, M. Kehry, and R. Hoelle. 1995. Studies on the interdependence of gp39 and B7 expression and function during antigen-specific immune responses. Eur. J. Immunol. 25:596-603.

55. Matzinger, P. 1994. Tolerance, danger, and extended family. Annu. Rev. Immunol. 12:991-1045.

56. Durie, F.H., A. Aruffo, J. Ledbetter, K.M. Crassi, W.R. Green, and L.D. Fast. 1994. Antibody to ligand of CD40, gp39, blocks the occurrence of the acute and chronic forms of graft-vs-host disease. J. Clin. Invest. 94:1333-1338.

57. Mohan, C., Y. Shi, J.D. Laman, and S.K. Datta. 1995. Interaction between CD40 and its ligand gp39 in the development of murine lupus nephritis. J. Immunol. 154:1470-1480. 